\title{
Igreja: uma reflexão sobre sua importância social
}

\author{
Adriano Silva Fermiano*
}

\section{Resumo}

Tendo em vista que a igreja encontra-se inserida na sociedade e com ela vive e vivencia suas dores, inseguranças e faltas em suas mais diversas áreas. Procurou-se demonstrar o envolvimento da Igreja do século I com a sociedade, tendo como exemplo a Igreja de Jerusalém. Apresentar a importância da Igreja do século XXI, através de suas ações junto a sociedade. Apontar para uma igreja que ainda hoje aplica-se em servir ao mundo. Realizou-se então uma pesquisa desenvolvida na modalidade bibliográfica. Diane disto, verificamos que a Igreja, desde a sua formação no século I, vivenciava de maneira prática o mandamento do amor ao próximo. Que a Igreja do século XXI, mantendo a centralidade do primeiro mandamento, continua sendo um corpo vivo e social. E apontamos uma Igreja que ainda hoje, continua a servir o mundo, o que impõe a constatação de que a Igreja, apesar dos desafios apresentados pela cultura e modo de viver da sociedade, tem suas ações norteadas pelo imutável mandamento do amor ao próximo.

Palavras-chave: Igreja; práxis; sociedade; cultura; desafio.

\section{Introdução}

Vive-se em um tempo em que o cristianismo, apesar de templos lotados, não consegue vivenciar suas primícias e seus valores, tornando-o malvisto e criando um distanciamento de quem deveria ser parte integrante, a sociedade. Esta negatividade é potencializada pela sociedade do espetáculo que se utiliza da mídia para vender um serviço chamado religião, de um "Deus" que faz a vontade daquele/a que paga (oferta e dizima) pelo serviço. Fazendo com que na atualidade, o bezerro de ouro seja a benção.

\footnotetext{
* Graduando em Teologia pela Faculdade de Teologia da Universidade Metodista de São Paulo, Polo Niterói. Matrícula 251772. Trabalho de Conclusão de Curso com vistas à obtenção de grau de Bacharel em Teologia, sob a orientação do Prof. Me. Marcos Aurélio da Silva.
} 
Neste sentido, este trabalho propõe-se a demonstrar a importância da Igreja para a sociedade através de suas ações. O objetivo geral é demonstrar aos leitores que a Igreja é integrada a sociedade e não um grupo de indivíduos que se reúne somente para adorar a um Deus “invisível”, mas, antes, é um Corpo com uma missão de demonstrar na prática que Deus sempre esteve e sempre estará presente não somente na vida mais no cuidado para com todos/as. Sendo assim, buscou-se, exemplificada na Igreja de Jerusalém, demonstrar que a Igreja sempre foi envolvida com a sociedade e com ela, vivencia suas dores, inseguranças e faltas. Avançou-se para o século XXI e se verificou em uma sociedade pós-moderna os desafios para o anuncio de uma religião absolutista que diz existir somente um único caminho, uma única verdade e somente uma única maneira de se achegar a Deus. Apontou-se para uma Igreja que ainda aplica-se em servir, Igreja esta que encontra-se fora da mídia, que está onde é preciso estar e que entre um culto e outro cumpre sua missão.

Para tal, a metodologia utilizada foi desenvolvida na modalidade bibliográfica, onde recorreu-se a diversas literaturas. Sendo as principais: Marcos Azevedo. Ética \& Espiritualidade: em busca de uma cidadania integral; Clovis Pinto de Castro. Por uma fé cidadã: a dimensão pública da Igreja: fundamentos para uma Pastoral da Cidadania; Richard J. Foster. A liberdade da simplicidade: encontrando harmonia num mundo complexo; Vanderlei Gianastacio. Responsabilidade social, serviço e cidadania: à luz da Igreja primitiva; Stanley J. Grenz. Pós-modernismo: um guia para entender a filosofia do nosso tempo; Jean-Francois Lyotard. O pós-moderno; Luiz Carlos Ramos. A sociedade do espetáculo e o discurso religioso e, ainda RAMOS, Igreja, culto e missão: Considerações eclesiológicas e missiológicas sobre a liturgia cristã; Helmut Renders. A soteriologia social de John Wesley e Gerd Theissen em A religião dos primeiros cristãos: uma teoria do cristianismo primitivo; entre outros.

Para uma linha de entendimento claro, organizamos as seções da seguinte maneira:

Na primeira seção objetivou-se demonstrar a inerência da Igreja na e com a sociedade deste o seu cerne, ou seja, desde a Igreja primitiva. Pode-se observar aqui que o mandamento do amor ao próximo encontra-se na Bíblia desde o Antigo Testamento, mas, que os judeus tornaram este mandamento somente algo teórico e o servir à Deus em uma religião ad intra. Verificou-se que Jesus faz uma nova releitura sobre o mandamento 
do amor ao próximo e o coloca lado-a-lado com o maior mandamento, trazendo em si, uma nova ordem social. Exemplificou-se na Igreja de Jerusalém a prática dessa nova ordem social.

Na segunda seção o objetivo foi de demonstrar a importância social da Igreja através de suas ações junto a sociedade. Foi necessário situar a Igreja dentro de uma sociedade chamada de pós-moderna com seus desafios. De forma a não causar conflitos, que não são alvos desta pesquisa, criou-se uma definição da palavra Igreja, com letra maiúscula e minúscula. Esta definição é para diferenciar a Igreja, corpo vivo e social, da igreja fruto da mídia e da sociedade do espetáculo que vende o serviço da religião. Nesta seção pode-se verificar que a Igreja não para e que entre um culto e outro cumpre a sua missão de ser um corpo vivo e social, demonstrando assim, em ações, sua importância junto a sociedade.

A terceira seção tem por objetivo apontar para uma Igreja que ainda hoje aplicase em servir ao mundo, demonstrando na prática que o Deus que é transcendente é o mesmo Deus imanente. Para tal, primeiro foi necessário destacar porque a Igreja não encontra-se na mídia e não é apresentada na sociedade do espetáculo, para na sequência, apresentar uma Igreja que coadune ortodoxia e práxis, espiritualidade e ação social para demonstrar que o mandamento imutável do amor ao próximo foi, é e continuará sendo a missão e a razão de ser da Igreja.

Sendo assim, o leitor encontrará durante no trabalho apresentado, subsídios para identificar como a Igreja é integrada à sociedade e continua firme em seu propósito de cumprir sua missão. Bem como, compreender que a pós-modernidade e a sociedade do espetáculo trazem diversos desafios que a Igreja contemporânea precisa superar. 


\section{Os atos dos Apóstolos}

Nesta primeira parte demonstraremos como a igreja, desde sua fundação, é social. Ou seja, está inserida e envolvida com a sociedade de forma a trabalhar e se envolver para restaurar a dignidade humana de todo/a aquele/a que necessitava de auxílio. Poderíamos falar sobre todos os exemplos das igrejas primitivas apresentadas no livro de Atos, assim como, dos exemplos deixados pela igreja até o terceiro século. Porém, para sermos objetivos, falaremos da igreja de Jerusalém, que apesar de todas as dificuldades que enfrentava soube trabalhar em prol de uma ação social de relevância para o seu tempo.

Antes, vamos voltar à antiga aliança para entendermos que o amor sempre esteve dentro do contexto veterotestamentário e de forma bem resumida entender porque iremos centralizar nossa pesquisa no cristianismo primitivo e não no judaísmo primitivo.

\section{$O$ amor ao próximo presente na antiga aliança}

Não poderíamos iniciar sem afirmar que o amor ao próximo não é algo novo. Não é uma novidade que surge com Jesus e é explicitada com a igreja primitiva. Já pode ser encontrado no Antigo Testamento (AT) este mandamento. Em Levítico 19.18 podemos ler:

"Não te vingarás, nem guardarás ira contra os filhos do teu povo; mas amarás o teu próximo como a ti mesmo. Eu sou o Senhor."

Segundo Theissen, (2009, p.99) "Esse amor ao próximo liga-se, então, em Lv 19, a um etos-de-misericórdia oriental comum, que vale para os fracos, as viúvas e os órfãos...”. Esse amor descrito na primeira formulação a um povo nômade, que possuía a promessa de uma terra, mas que ainda não tinha lugar, já seria um indicativo do amor de Deus que romperia com a geografia e criaria uma expansão desse amor capaz de alcançar o inimigo, o estrangeiro e os fracos, socialmente falando.

Se continuarmos no Antigo Testamento perceberemos que o mandamento descrito em Levítico permeia as páginas da Bíblia. Em Deuteronômio podemos ter o conhecimento de que Deus não faz acepção de pessoas, defende a causa do órfão e da viúva e que ele ama ao estrangeiro (Dt. 10.17-18). Essas informações são afirmadas pelo salmista "O Senhor faz justiça e juízo a todos os oprimidos" (S1. 103.6). Podemos ainda citar a exortação feita pelo profeta Zacarias de executar o juízo verdadeiro, um para com 
o outro, de não oprimir a viúva, o órfão, o estrangeiro e nem ao pobre (Zc. 7.9-10). "As leis que podemos chamar, 'da compaixão e do cuidado' estão presentes em todo o texto da antiga aliança." (FOSTER, 2008, p. 52). Contudo, esse "amor ao próximo" foi se restringindo, tornando-se cada vez mais ad intra povo. O mandamento que poderia romper as fronteiras tem os seus portões fechados. Restringido a mandamentos teóricos. Talvez pela condição de povo santo e escolhido por Deus (Dt. 7.6). Quem sabe, por admoestações de não se misturarem com outros povos (Dt. 7.2-4) ou ainda, que as outras nações seriam como armadilhas e laços que serviriam para afastar o povo da presença de Deus (Js. 23.13). Seja como for, o profeta Oséias deixa claro a falha do povo santo e escolhido, do povo puro de anunciar o Deus de Israel à outras nações "Ouvi a palavra do Senhor, vós, filhos de Israel, porque o Senhor tem uma contenta com os habitantes da terra, porque não há verdade, nem benignidade, nem conhecimento de Deus na terra." (Os. 4.1).

Diversas citações bíblicas poderiam ser descritas para expressar o "apelo" de Deus a prática da justiça através de seus profetas e como estes denunciavam as injustiças cometidas pelos sacerdotes e pelo povo. "Somos informados de que Deus rejeitava os rituais sagrados de Judá porque eles haviam perdido o senso de responsabilidade social." (FOSTER, 2008, p. 49)

Podemos verificar que o amor, o cuidado e a compaixão sempre estiveram na intencionalidade de Deus, mas, que o judaísmo primitivo não conseguiu acolher e nem expandir. Antes pelo contrário, desviaram-se dele e restringiram o mandamento do amor ao próximo a um mandamento teórico, uma máscara, uma vestimenta usada por aqueles que deveriam praticar e levar a justiça social a todos. Estes, que posteriormente, são duramente criticados por Jesus, os escribas e fariseus.

\section{Igreja de Jerusalém: mais do que uma ação social, um envolvimento com a sociedade}

Como vimos anteriormente, o judaísmo primitivo não conseguiu acolher e expandir o amor ao próximo reduzindo-o, ou isolando o seu amplo sentido a algo para dentro de si mesmo. Fato este que chega ao tempo de Jesus e na igreja incipiente através dos escribas e fariseus.

A religiosidade dos escribas e fariseus, enraizada numa compreensão equivocada de justiça (isolada de seu campo semântico), era excludente, hipócrita, opressora, preconceituosa, discursiva 
(teórica), escravizante. Viviam uma espiritualidade superficial, das aparências, da fachada (sepulcros caiados), em que não havia espaço para a misericórdia e para o acolhimento aos pecadores, especialmente os pobres e necessitados. Eles praticavam 'boas obras', mas não possuíam bondade, compaixão e fidelidade. (CASTRO, 2000, p. 95)

Os fariseus e escribas da época de Jesus deixam claro a forma de como eles tratavam a questão do amor ao próximo e o envolvimento social. Que a pesar de ser um mandamento, descrito na lei e anunciado e denunciado pelos profetas, chega ao tempo de Jesus como uma vestimenta, um adorno com a "cor da hipocrisia". Fariseus e escribas, conhecedores de toda a lei. Contudo, duramente censurados por Jesus (cf. Mt 23.1-7).

É na perspectiva de Jesus de amor ao próximo que falaremos sobre a igreja de Jerusalém. Para entendermos como iniciou-se o envolvimento da igreja de Jerusalém com a sociedade de seu tempo, voltemos ao sermão da montanha. Em Mateus 5.43-46 Jesus expande o significado que encontramos em Levíticos 19.18. Theissen (2009, p. 101-102) coloca esse relato de Jesus sobre amor ao próximo em três partes. A primeira ele diz que o amor ao próximo se torna o amor pelo inimigo e, não um inimigo pessoal, mas inimigos que possuem poder para perseguir e discriminar. Em segundo o amor ao próximo se torna o amor ao estrangeiro, exemplificando com a parábola do bom samaritano (Lc 10.25-37) onde o samaritano mostra-se como o próximo "não em razão de uma condição preexistente, mas por causa de sua atitude." Em terceiro o amor ao próximo se torna o amor aos pecadores, trazendo como reflexão a mulher pecadora que ungiu os pés de Jesus (Lc 7.36-38), uma mulher que é discriminada pelos outros, mas é acolhida por Jesus.

A diferença entre o amor ao próximo descrito no AT e o amor ao próximo descrito no Novo Testamento (NT) é que no NT o amor ao próximo não é mais um mandamento, ele é colocado no centro e descrito como estar em igualdade com o primeiro e grande mandamento (cf. Mt 22.35-40). É a partir dessa percepção de amor ao próximo, que o cristianismo primitivo lança os seus alicerces e constrói suas bases.

Nos evangelhos, Jesus não só traz de volta o amor e o cuidado para com o próximo, como também, implementa uma nova ordem a quem possuía bens e desejava segui-lo “... Se queres ser perfeito, vai, vende tudo o que tens, dá aos pobres e terás um tesouro no céu; e vem e segue-me.” (Mt 19.21). “... a mensagem de Jesus foi projetada, para ser um desafio direto aos ricos e poderosos, fossem eles os ocupantes, em Roma, os 
colaboradores do Templo ou a nova classe endinheirada [sic] nas cidades gregas..." (ASLAN, 2013, p. 119). Isso, trouxe uma nova ordem social.

Olhando para o Livro de Atos, podemos perceber que a Igreja Primitiva deu continuidade a essa nova ordem. Podemos afirmar isso olhando para a igreja de Jerusalém, uma igreja com raízes profundas na cultura judaica. Essa igreja, formada por judeus hebreus e helenistas, realiza sua ação social junto as pessoas. "No seu conceito de ação na sociedade, [...] a vida em comum naquela igreja era tão valorizada que se destacou pela assistência oferecida as pessoas.” (GIANASTACIO, 2012, p. 40)

Não queremos criar uma fantasia sobre o mundo perfeito na igreja de Jerusalém. Não era. A igreja de Jerusalém passava por diversas dificuldades em sua época, em especial financeira. Jeremias (1983, p. 166) nos relata que por ser a Cidade Santa "Jerusalém no tempo de Jesus, apresentava-se como um centro de mendicância" e haviam "pessoas que simulavam a cegueira, fingiam-se de surdas, estropiadas, coxas e etc." Sider (1984, p.106-107) nos informa que "Jerusalém atraía um número de pobres fora do comum", que "uma grande quantidade de pessoas idosas se dirigia a Jerusalém para lá morrerem ou esperar o Messias”. Isso não era tudo. Várias calamidades naturais seguidas de longos períodos de fome assolaram Jerusalém.

Muitos eram os problemas, mas, as Escrituras relatam que uma denúncia específica, as viúvas estarem sendo esquecidas na distribuição diária (At 6.1), fez com que a igreja de Jerusalém se organizasse e estabelecesse o seu ministério de ação social, aqueles que serviriam a mesa. A eleição de sete judeus helenistas, que possuíam qualidades específicas (At 6.3), concretizaria e organizaria uma estrutura voltada e destinada a recolher, administrar e servir aos necessitados.

O seu compartilhar não era superficial e ocasional. Regular e repetidamente 'vendiam as suas propriedades $\mathrm{e}$ bens $\mathrm{e}$ distribuíam a todos, à medida que alguém tinha necessidade'. Se a necessidade era maior do que as reservas em caixa, eles vendiam propriedades. Simplesmente davam até que as necessidades fossem supridas." (SIDER, 1984, p.105)

A ação social da igreja de Jerusalém não era meramente assistencialista, bem como, a venda de bens para a distribuição aos pobres não era uma espécie de "mística". Antes era uma ajuda real estendida a toda a comunidade. 
O fato de pessoas ricas contribuírem não se tratava de esmola ou benfeitorias, mas antes, de um profundo senso de dever e uma profunda consciência de amor ao próximo. “O fato de os ricos entre eles terem contribuído com grande generosidade para remediar uma desesperadora necessidade no corpo de Cristo não é sinal de um idealismo ingênuo, mas, muito antes, de um discipulado incondicional.” (SIDER, 1984, p.107). Ensinamento este transmitido e vivenciado pelos apóstolos, não como mais um mandamento, mas como a forma de glorificar a Deus através da vida de alguém que antes era chamado de outro, mas que em Jesus passa a ser chamado de próximo.

Nenhuma das dificuldades foi um impeditivo para que a igreja de Jerusalém deixasse de socorrer seus necessitados. Servir e ajudar ao próximo era um estilo de vida para os cristãos primitivos. "Não se tratava de mero ensino teórico, e sim de prática vivida" (GIANASTASIO, 2006, p. 53).

Podemos verificar o quanto a igreja de Jerusalém era envolvida com a sociedade e principalmente com os problemas sociais. Os relatos no livro de Atos, bem como, em nenhuma das biografias consultadas, apresenta a igreja agindo por solicitação e ou exigência de alguma autoridade romana. Antes, suas ações e seu envolvimento com a sociedade ocorriam pelo fato de Jesus assim os terem ensinados “...amai-vos uns aos outros como eu vos amei" (Jo 13.34).

A igreja em Jerusalém não foi capaz de resolver o problema da mendicância e suprir a necessidade de todos/as, mas com certeza contribuiu para que houvesse uma restauração da dignidade humana e para libertar o rico de sua riqueza (o individualista onde seu coração encontrava-se somente em sua riqueza) e o pobre de sua necessidade.

No segundo capítulo, avançaremos para a contemporaneidade, falaremos sobre o contexto pós-moderno em que a igreja se encontra e buscaremos demonstrar a importância da igreja, através de suas ações junto a sociedade e descrever como a igreja deixa de ser somente uma instituição para tornar-se um corpo vivo e social, a exemplo da igreja de Jerusalém. 


\section{Igreja: mais do que uma instituição, um Corpo vivo \& social}

Demos um grande salto no tempo! Saímos da igreja do primeiro século e avançamos direto para a igreja do século XXI. Vimos que a igreja de Jerusalém, apesar de todos os problemas era uma igreja totalmente envolvida com a sociedade, que o mandamento do amor ao próximo era um etos, um estilo de vida que os primeiros cristãos levavam muito a sério. Mas, e a igreja do século XXI, o que tem feito? Antes de respondermos a esta pergunta, vamos entender o contexto social e cultural em que a igreja atual se encontra.

\section{Pós-modernidade: tempos difíceis para uma fé absolutista}

Estamos em um tempo chamado de pós-moderno onde tudo é relativo, não existem mais verdades absolutas ou convicções últimas. "O espírito pós-moderno é bastante humilde para proibir e bastante fraco para banir os excessos[...]" (BAUMAN, 1998, p. 205). Então, o que prevalece e quem está com a razão? Se a bússola já não aponta para o norte, onde é o caminho? A pós-modernidade nos traz muitas perguntas e poucas resposta objetivas, este é o seu propósito. Stanley J. Grenz, traz a teoria de alguns filósofos em especial de Foucault e de Rort sobre o pensamento pós-moderno, nos diz Grenz que “Os filósofos pós-modernos aplicaram as teorias do desconstrucionismo literário ao mundo todo." Michel Foucault declara que toda afirmação de conhecimento é um ato de poder. Richard Rort propõe a substituição da filosofia sistemática pela filosofia da construção, onde segundo ele, o objetivo é dar prosseguimento ao diálogo e não a descoberta da verdade. Na obra de ambos “Tudo se resume a diferença." (GRENZ, 2008, p. 22-23). Assim, como a igreja consegue anunciar uma fé absolutista? Já que ela afirma que só existe um caminho, uma única verdade e um único modo de se chegar a Deus (JO 14.6)

Para tentarmos responder a esta pergunta, em primeiro lugar, não podemos olhar para a igreja primitiva com um olhar nostálgico e querendo agir da mesma maneira como os cristãos incipientes agiram em seu tempo. A vivência e a proximidade com Jesus, o modo de vida e a condição sócio-política e cultural, proporcionaram o desenvolvimento e a ação da igreja primitiva. Aprendemos com a história, Deus é parte dela. A própria história é dividida entre antes e depois de Cristo. Afinal, "não somos chamados a ministrar 
a uma época remota, mas aos dias de hoje, cujo o contexto acha-se sob a influência da pós-modernidade.” (GRENZ, 2008, p. 28)

Estamos no pós-modernismo, uma era que recusa a verdade objetiva, ao menos o entendimento clássico ao seu respeito, mina as reivindicações cristãs de que ela apresenta a verdade objetiva, esse tempo exerce grande influência sobre a vida dos jovens dessa nova geração, que aceitam com naturalidade a era da informação cinematográfica e televisiva pois disseminam todo tipo de informação. Isso traz implicações ao anuncio e a comunicação do Evangelho, já que cada vez mais o diálogo formal vai se tornando raro e ao mesmo tempo "raso". Precisamos ordenar nossos pensamentos de modo que possamos compreender a fé cristã para que possamos saber como apresentar o Evangelho a esta nova geração. (GRENZ, 2008)

Cabe então a essa geração anunciar e aprender a comunicar o Evangelho à uma sociedade relativista. Francis A. Schaeffer vai nos dizer:

Cada geração cristã defronta com este problema de aprender como falar ao seu tempo de maneira comunicativa. É problema que se não pode resolver sem uma compreensão da situação existencial, em constante mudança, com que defronta. Para que consigamos comunicar a fé cristã de modo eficiente, portanto, temos que conhecer e entender as formas de pensamento da nossa geração. (SCHAEFFER, 2014, p. 2)

O Cristão de hoje precisa aprender sobre o seu contexto social e como se comunicar com esta sociedade. Não podemos olhar para trás e utilizar as mesma falas e métodos utilizados anteriormente. O tempo mudou. A sociedade mudou, e com ela a forma de pensar, agir e principalmente de se comunicar. Precisamos nos fazer compreendidos e ter a certeza de que a outra parte está sendo parte integrante nesse processo de comunicação e anúncio. Não nos cabe hoje anunciar para alguém um Jesus de mudanças futurística e escatológicas, onde após a pessoa aceitar Jesus simplesmente dizemos que ela já pode morrer pois sua alma já foi salva. A alma não é mais importante do que o corpo. O Deus que é transcendente é o mesmo Deus que é imanente. "Deus criou o homem no seu todo e o homem todo é importante." (SCHAEFFER, 2014, p. 13) JeanPaul Sartre (apud SCHAEFFER, 2014) afirma que a grande questão filosófica é que algo existe e não que nada existe. E é o cristianismo que tem a resposta para essa existência objetiva. 
Uma parte da vocação cristã consiste em avaliar todos os novos espíritos característicos que moldam a cultura na qual Deus chama os crentes para viverem como povo seu. Um dos objetivos dessa tarefa consiste em equipar a igreja de modo que ela expresse claramente o evangelho e o encarne no contexto daquela cultura. Atualmente, somos desafiados a viver em conformidade com nosso compromisso cristão em meio a uma cultura e a proclamar o evangelho a uma geração que, cada vez mais, é pós-moderna em seu modo de pensar. (GRENZ, 2008, p. 242)

Compreender e conhecer o contexto social e cultural em que vivemos. Aprender a se comunicar na era virtual de maneira a encontrar a pessoa real por trás de um post, de emoji ou de um meme. Relacionar-se de forma concreta com essa pessoa e deixar que ela veja em nós que existe um Deus relacional e real que se importa com ela em todas as áreas da sua vida. Dentro deste contexto anunciamos uma fé absolutista, respeitando a integralidade do outro e da outra, sem perder de vista os nossos princípios e valores. Nas palavras de Júlio Zabatiero (apud SILVA, 2009, p. 28), “a evangelização é uma ação fundamentada na compaixão e na fidelidade ao Evangelho".

\section{A Igreja que entre um culto e outro cumpre a sua missão}

Não é pretensão deste trabalho fazer críticas às instituições, uma vez que a expressão evangelicalismo, utilizada para expressar o movimento evangélico, é utilizada em muitas obras tanto de forma positiva quanto pejorativa, devido a multiplicidade com que as instituições igrejas vem surgindo e agindo. Sendo assim, a partir daqui, faremos uma definição que nos ajudará a prosseguir sem incorrer no risco de julgar ou criticar.

Em primeiro lugar definiremos os termos Igreja e igreja. Para Igreja com letra maiúscula, utilizaremos uma definição de J. J. Castilho (apud GIANASTACIO, 2012, p. 20) "refere-se às igrejas locais, ou seja, pessoas cristãs que se organizam em um determinado local para desenvolver a obra de Deus, independentemente da denominação". Este termo utilizaremos para falar do Corpo Vivo \& Social. Para a palavra igreja, no minúsculo, utilizaremos para falar da igreja enquanto instituição somente. Locais organizados como empresas de prestação de serviços ou venda de produtos, mas sem expressão ou ação na obra de Deus. Neste sentido AZEVEDO (2015, p. 13) nos dirá: "A igreja, assim como toda a forma de religiosidade no mundo moderno, é vista como um departamento da vida privada, mas não como centro de referência de valores, costumes e propósitos”. 
Para entendermos melhor o porquê dessa definição utilizaremos um comparativo com uma afirmação feita pelo professor e teólogo Luiz Carlos Ramos no que se refere a comparação entre Igreja e culto, ele nos diz: "Ao que parece, o senso comum confunde, amiúde, igreja com culto[...] Reduzir a experiência eclesiológica ao culto resultaria num empobrecimento tamanho que desqualificaria a Igreja como tal” (RAMOS, 2011). Da mesma forma comparar a ação da Igreja a uma concentração de pessoas em um determinado lugar ou a um movimento de autopromoção seria desqualificar a ação de Deus na humanidade, reduzindo a meros encontros a proposta do Evangelho. Na letra da música "É proibido pensar" de Jorge Alexandre seria: "Reconstruindo o que Jesus derrubou; Recosturando o véu que a cruz já rasgou; Ressuscitando a lei, pisando na graça; Negociando com Deus".

Vimos anteriormente que a pós-modernidade é um grande desafio para a igreja contemporânea. O que antes seriam verdades absolutas hoje são prestação de serviços e venda de produtos. Neste sentido Marcos Azevedo faz a seguinte afirmação:

Nessa perspectiva, não é mais Deus quem nos escolhe; o homem é quem o seleciona na prateleira do supermercado[...] O problema do homem (pós) moderno, não é a falta de religião, o ateísmo e o secularismo, mas, ao contrário, a superoferta de sentido religioso que o cerca por todos os lados[...] que buscam atender as necessidades individuais das pessoas, pois elas são vistas como clientes dentro desse novo e promissor mercado religioso. (AZEVEDO, 2015, p. 15-16, itálico do autor)

Essa superoferta de igrejas como prestadoras de serviço e venda de produtos não respondem às expectativas e aos anseios dessa sociedade. "Algumas igrejas se apresentam como ilusórias redomas protetoras do mal da sociedade globalizada; outras fazendo o próprio jogo dessa cultura, sacrificando valores cristãos em honra aos ídolos do mercado". (SILVA E XAVIER, 2007, p. 165).

Apesar de todos os desafios apresentados na pós-modernidade, a Igreja não para. A Igreja não olha para o futuro a partir do seu presente ou passado, ao invés, olha o presente a partir do futuro, vê o seu potencial e aceita os desafios estabelecidos por Deus. (AZEVEDO, 2015) A Igreja entende que, a pesar da promessa de novo céu e nova terra, a missão é para o tempo presente. É compreender que somos parte do Reino de Deus na terra em uma atuação social e pessoal para resgatar a dignidade humana. Isso é a atitude de Cristo, através da ação do Espírito, de uma obediência ao Pai no serviço ao próximo, 
onde o Espírito de Jesus é essencialmente de abertura e de comunhão. (SILVA E XAVIER, 2007)

A Igreja é atemporal, em sua historicidade ela sempre esteve envolvida com a sociedade. Em alguns momentos de forma mais representativa, em outros nem tanto. Em tempos trazendo para a si a responsabilidade social e se sacrificando por esta sociedade, como podemos verificar na Igreja dos primeiros séculos, com os Moravianos, com John Wesley e em outros movimentos ao longo da história. Mas também houve momentos de trevas onde a Igreja se tornou igreja, mantendo-se calada diante da opressão e da necessidade do povo, impondo sua vontade em nome de um Deus que não é o Deus da Bíblia. A igreja do século XXI vive essa mistura de acontecimentos. Muitos templos lotados de pessoas que estão no que seria o "lugar santo" e ainda sim, perdidas e na miséria, sendo manipuladas e com suas almas vazias, mas, a Igreja não está nestes templos. Não que ela não pare para adorar à Deus, é que ela tem a consciência de que a missão acontece entre um culto e outro. Neste contexto nos diria RAMOS (2011): "a Igreja interrompe sua caminhada rumo à liturgia para uma ação missionária sensorial e concreta [...]. Quando, finalmente a Igreja e o Mundo se dão as mãos e passam a caminhar juntos, aí sim chega a vez do culto".

A Igreja cultua à Deus. Contudo, ela tem em seu coração de que seguir a Jesus Cristo é deixar-se imbuir pelo próprio ministério da sua solidariedade que na relação de unidade com ele o crente se vê implicado em uma experiência de unidade com as pessoas (SILVA E XAVIER, 2007), nessa relação de solidariedade, amor e compaixão para com o próximo que a missão de Deus acontece, e é no acontecer dessa missão que a Igreja permanece um Corpo Vivo \& Social. Um corpo que continua em movimento em direção a todo aquele e aquela que necessita encontrar o caminho de Deus e neste caminho se encontrar e tem sua condição vivencial resgatada.

Para não parecer que estamos falando da atuação da Igreja no século XXI de forma subjetiva, vamos dar um exemplo prático, o que no próximo capítulo o faremos com mais assuntos ligados ao nosso cotidiano. Em seu relatório de 2017, a Visão Mundial, uma organização cristã de desenvolvimento, advocacy e resposta às situações de emergência, que hoje encontra-se em atuação em mais de 99 países, inclusive no Brasil, onde atua a mais de 42 anos. Conseguiu apadrinhar 3.200.000 crianças e beneficiar outras 41 milhões (Visão Mundial, Relatório, 2017) com ações práticas nas mais diversas áreas de atuação 
social. Sendo uma organização envolvida diretamente com e na realidade da sociedade. Através de seus projetos consegue alcançar e resgatar a dignidade humana de várias comunidades.

Na e para a Igreja onde Cristo é o cabeça existe uma nova humanidade e um movimento realizado pela espiritualidade da graça. Neste sentido Julio Zabatiero afirma:

A espiritualidade da graça propõe o jogo da possibilidade, não do dever. A espiritualidade cristã conjuga o projeto "seja aquilo que Deus fez de você, em Cristo". Este novo estilo de vida, o novo homem, permanentemente se "renova para o pleno conhecimento segundo a imagem daquele que o criou" e nele não há mais lugar para as divisões introduzidas no mundo pelo pecado humano. As diferenças étnicas, religiosas, raciais, econômicas, culturais e de gênero perderam todo o valor, pois na nova humanidade "Cristo é tudo em todos" (v. GI 3:28: "pois todos sois um em Cristo Jesus"). (ZABATIERO, 2005, p. 96)

Um Corpo Vivo \& Social permanece sempre em movimento e está sempre onde é necessário estar. Para a Igreja o olhar social e pessoal não julgam pela maneira como a sociedade ou o indivíduo encontram-se, mas pela compaixão e pela consciência de que existe nesta Igreja a possibilidade de ser o canal, o meio, pelo qual Deus poderá alcançar este indivíduo e resgatar sua dignidade humana. As diferenças diversas não são impeditivas para a atuação, pois, aquele e aquela que é Igreja, tem a consciência de que nada pode nos separar do amor de Deus que está em Cristo Jesus (RM 8.39) e como disse o próprio Zabatiero, na citação acima, essas diferenças perdem "todo o valor, pois na nova humanidade Cristo é tudo em todos".

Com isso, respondemos à pergunta inicial de o que a Igreja do século XXI está fazendo, bem como, conseguimos demonstrar a sua importância junto à sociedade. Poderíamos citar a atuação da Igreja na política, junto às instituições carcerárias, em visitações aos hospitalizados e entre muitas outras áreas. Alguém já disse que Deus tem os seus meios de agir, e dizem também que é sempre no silêncio. O que queremos dizer com isso é que a Igreja continua agindo entre um culto e outro. Não encontramos a ação da Igreja na mídia televisiva ou no rádio ou nas redes sociais. Suas ações encontram-se nas cracolândias, junto às prostitutas durante as madrugadas, entre um programa e outro, junto aos mendigos e moradores de rua, provendo abrigo e cuidados aos dependentes químicos. Resgatando, tratando, recuperando a dignidade humana daqueles e daquelas que o poder público não consegue alcançar. São nesses lugares e junto a estas pessoas 
que a Igreja poderá ser encontrada, agindo em prol da sociedade e do ser humano. É assim que a Igreja, através de ações que coadune ortodoxia e práxis, está e demonstra sua importância na e para a sociedade.

Em nosso próximo capítulo daremos continuidade a atuação da Igreja e apontaremos para uma Igreja que ainda hoje aplica-se em servir ao mundo, demonstrando na prática que o Deus que é transcendente é o mesmo Deus imanente. Uma Igreja que encontra sua espiritualidade na justiça, no Reino de Deus e na diaconia.

\section{Fora da mídia: a Igreja servidora}

Aqui continuaremos a utilizar a definição de Igreja e igreja que adotamos no capítulo anterior. Sendo assim, como já vimos anteriormente a Igreja não está na mídia ela se encontra onde precisa estar, ou seja, onde existe a necessidade de se estar. Antes de continuarmos, um esclarecimento é necessário. Não é fonte de nosso estudo a sociedade do espetáculo, estamos trazendo apenas uma conceituação do porquê que a Igreja servidora está fora da mídia.

Vimos no capítulo anterior que estamos na pós-modernidade e neste mesmo contexto nos encontramos na sociedade do espetáculo. Guy Debord "cunhou a expressão sociedade do espetáculo para designar e caracterizar o tipo de cultura da mídia que estava sendo implementada desde meados do séc. XX; e que, desde os anos 60 , já tendia a tornarse hegemônica.” (RAMOS, 2008, p. 144). Desde então a espetacularização da religião tem trazido pontos negativos. Para Debord, dentro do contexto apresentado por Luiz Carlos Ramos em seu trabalho, a espetacularização traz uma inversão da vida e da realidade. Neste sentido nos diz Ramos:

\footnotetext{
"[...]a compreensão do que afirma Debord sobre a "inversão" da vida, isto é, do espetáculo como "movimento autônomo do não-vivo". Daí que todo espetáculo, por apresentar-se como reflexo do real, como em espelho, é sempre uma imagem invertida do real. Isto é, se do lado de cá da superfície espetacular está a vida, do outro lado está a não-vida, ou uma ilusão/imagem/representação da vida. Por mais parecidas que sejam, a imagem e a realidade não são a mesma coisa. São, antes, o inverso ou reverso uma da outra." (RAMOS, 2008, p. 144).
}

A sociedade do espetáculo tem invertido e ou distorcido a realidade do que é a verdadeira proposta do Evangelho, social e comunitária, para um "mundo" de individualistas preocupados somente com a sua própria imagem refletida no espelho. 
Transformando fiéis em consumidores de seus espetáculos. "Não se trata, porém, de oposição entre realidade e espetáculo, mas de desdobramento essencial, no qual a alienação é recíproca [...] "a realidade surge no espetáculo, e o espetáculo é real". (RAMOS, 2008, p. 145) A “invasão" do espetacular torna o espetáculo em um conceito real, vivo e influenciador. Por isso quanto mais se comtempla o espetáculo, menos se vive, pois, o espetáculo causa a separação da vida para com a vida, tornando a vida um produto da espetacularização (RAMOS, 2008).

É por esta conceituação que a Igreja servidora não se encontra na mídia e não é parte da sociedade do espetáculo. A Igreja não para e, entre um culto e outro continua sua missão em ser um meio para a missio Dei. A Igreja não é um reflexo distorcido do real, antes, é o reflexo da realidade do Reino de Deus, sua vontade e sua justiça.

Enquanto a sociedade do espetáculo cria indivíduos, cada vez mais isolados em seus próprios interesses, solitários, escravos e consumidores da espetacularização do divino. A Igreja permanece na contramão deste mercado, unindo, agrupando, incluindo e resgatando o ser humano. A Igreja tem ações conjuntas e em conjunto, não leva em consideração seu viés ou sua denominação, para que a sua missão seja realizada. Não existem individualistas ou santos solitários nessa missão. Neste sentido Helmut Renders aponta um hinário dos irmãos Wesley e nos diz:

Porque a religião, na qual estes autores [os místicos, o autor] pretendem nos edificar, é uma religião solitária [...] O evangelho de Cristo está diretamente oposto a isso. Religião solitária não se encontra aqui. "Santos solitários" é uma frase nada mais consistente com o evangelho do que adúlteros santos. O evangelho de Cristo não reconhece nenhuma religião que não seja social; nenhuma outra santidade que não seja a (santidade) social; "Fé operando pelo amor" é o cumprimento, a largura, a profundidade e a altura da perfeição cristã. (RENDERS, 2006, p.46 - grifo do autor)

A Igreja propõe e realiza na sociedade ações comunitárias e inclusivas, ações que demonstrem que a Igreja é integrada à sociedade e sua comunidade e não um grupo de indivíduos que se reúnem somente para adorar a um Deus “invisível”, mas, antes, é um Corpo com uma missão de praticar e na prática apresentar um Deus que sempre esteve e sempre estará presente na vida, no cotidiano e no cuidado para com todos/as. Isso relata a unidade da Igreja para a realização da sua missão de anunciar e compartilhar seu maior tesouro. "O tesouro da Igreja é o evangelho, a mensagem que consiste em todo o plano 
de Deus em salvar o homem pecador, proclamando, ensinando e testemunhando com a vida a história da salvação[...]" (AZEVEDO, 2015, p. 45, grifo meu)

A Igreja na vivencia de sua espiritualidade encontra no outro o seu motivo de existir e ser, afinal essa é sua missão, de encontrar e se encontrar com o outro “[...] nessa perspectiva aproxima-se a questão da união com Cristo (ou Deus) com a descoberta do Cristo no rosto do outro [...]" (RENDERS, 2006, p.43). A missão da Igreja, através da diaconia comunitária, é em ser o canal, o meio pelo qual o outro encontrará o Deus que em Cristo continua reconciliando consigo mesmo o mundo. Jesus Cristo, que em si, trás a centralidade do Reino de Deus e apresenta o caminho para se encontrar com o Pai. GONÇALVES (2009, p. 34) nos diz que "Para entender o Reino, é preciso ir a Jesus. Para conhecer Jesus, é preciso ir ao Reino de Deus. [...] Em Jesus se dá o caminho para o Pai e para o Reino.” E nisso está a espiritualidade da Igreja que indo de encontro ao outro, encontra à Cristo, encontrando Cristo, encontra o Reino e encontrando o Reino este se expande e se expandindo a vontade de Deus vai se tornando conhecida e sua justiça vai sendo implantada e implementada onde "pela força transformadora da Palavra feita carne deverá continuar vindo ao encontro do mais profundo desejo humano de sonhar com um mundo mais justo, mais fraterno, mais livre.” (SILVA E XAVIER, 2007, p. 113).

\section{A igreja servidora}

Quando falamos que a Igreja está fora da mídia, não estamos dizendo que esta Igreja se encontra bitolada e ou é ignorante sobre os meios de comunicação de massa, seja a televisão, rádio, internet ou redes sociais. O que estamos dizendo é que a Igreja não se utiliza da mídia para autopromoção, angariar fundos ou "espetacularizar" a vida e a religião. A Igreja segue para onde o poder público não chega (não consegue, não tem interesse ou não consegue atender em sua totalidade), ela vai se encontrar com o outro para resgatar, incluir e apontar, em Cristo, novas possibilidades, nova vida. Sendo assim, vamos dar continuidade exemplificando onde a Igreja do século XXI vem atuando:

Cracolândias: Exemplos como a da pastora Nildes Néri que foi alvo de uma reportagem para o G1 de São Paulo em junho de 2017 sobre sua atuação junto aos dependentes químicos, onde durante a reportagem ela faz a seguinte declaração: "É um chamado incondicional, não é pela religião, não é pela igreja. Eu entendo que eu, como cristã, tenho uma responsabilidade.” (G1, 2017). Podemos citar a reportagem do jornal Folha de São 
Paulo que em maio de 2018 lança uma matéria com o seguinte tema: "Igrejas atuam onde Estado não pisa para atender usuários na cracolândias." (FOLHA DE SÃO PAULO, 2018). Já o O São Paulo, em maio de 2018, lança uma matéria falando sobre a experiência de outros países pelo mundo que também enfrentaram ou enfrentam o problema de aglomeração de pessoas para o uso de drogas e quando se refere ao Brasil, cita a cidade de São Paulo e relata o seguinte sobre a atuação das Igrejas nas cracolândias: "Em meio ao clima de desconfiança dos usuários, a Igreja é uma das poucas instituições que consegue manter um vínculo com os dependentes químicos." Outra citação nesta matéria é:

\footnotetext{
"Se a Igreja parasse de atuar na Cracolândia, esta provavelmente seria cinco vezes maior. Além da atuação presencial, vários grupos de pastoral fazem o acompanhamento das famílias dos usuários de drogas. Quando você trata o usuário de drogas, você precisa tratar as famílias também", afirmou Ana Maria.” (O SÃO PAULO, 2018)
}

No sistema prisional: a Segurança pública do governo do estado do Rio Grande do Sul realiza uma reunião com líderes cristãos para ampliar a atuação da Igreja dentro do sistema prisional. Durante a matéria O secretário da Segurança Pública, Cezar Schirmer, vai dizer: "Queremos garantir a todos que desejam a recuperação por meio da fé a oportunidade de estabelecer contato com as igrejas e participar ativamente das atividades" (SITE GOVERNO ESTADO DO RIO GRANDE DO SUL, 2016). O jornal O Globo publicou a matéria "Evangélicos marcam território dentro dos presídios do Rio" o destaque nesta matéria seria:

Esta predominância acompanha uma tendência de crescimento dos evangélicos na sociedade, apontada pelo Instituto Brasileiro de Geografia e Estatística (IBGE). Na pesquisa, percebemos que tanto para os detentos quanto para os funcionários das penitenciárias, a presença religiosa tem um efeito apaziguador e calmante em um ambiente muito tenso - destaca Fernandes, referindo-se ao crescimento de $61 \%$ dos evangélicos entre os Censos de 2000 e 2010. (O GLOBO, 2016)

Podemos citar diversas outras áreas de atuação da Igreja, como o trabalho da Igreja Batista de Água Branca (ibab) que possui um trabalho chamado Rede ibab Solidária "é um espaço de mobilização e cooperação entre a Igreja Batista de Água Branca e os projetos e organizações do terceiro setor e agências missionárias com os quais mantém relação e se identificam com a sua visão." Onde através desta rede de cooperação é possível alcançar diversas áreas de atuação. Uma delas é a ONG chamada AEBVB Associação Educacional e Beneficente Vale da Benção que possui o Programa 
Reconstruit - Apoio a Famílias Refugiadas - "oferece acolhimento integral, em sistema de casa de passagem, pelo período de aproximadamente seis meses. Apoia o refugiado e sua família com moradia, alimentação, aprendizado da Língua Portuguesa, imersão cultural, regularização de documentos, encaminhamento das crianças à rede pública de ensino, apoio para inserção ao mercado de trabalho, cuidados de saúde, psicológico e espiritual.” (REDE SOLIDÁRIA IBAB). Poderíamos ainda, citar o trabalho de diversas outras instituições como o Instituto Metodista Ana Gonzaga, que cuida de crianças e jovens carentes. Contudo entendemos que já conseguimos exemplificar a atuação da Igreja e sua importância social.

A Igreja não para, ela continua sua marcha em direção a todo aquele e aquela que necessita ser alcançado. Ela continua marchando no seu dia-a-dia em direção aos hospitais, presídios, comunidades, dependentes químicos e a todos e todas que são socialmente fragilizados ou desamparados. A Igreja é inclusiva, ou seja, é para todos e todas, pobres e ricos. A Igreja não enxerga, como já falamos no capítulo anterior, as diferenças sociais, de classe, cor, credo, etnia, gênero, econômica, pois em Cristo as diferenças perdem o seu valor. Pois o mandamento que está junto ao grande mandamento é e continuará sendo "amai-vos uns aos outros".

Aqui talvez caiba uma pontuação, ou seja, vale relembrar nossa definição de Igreja. Para Igreja com letra maiúscula, estamos utilizando uma definição de J. J. Castilho (apud GIANASTACIO, 2012, p. 20) "refere-se às igrejas locais, ou seja, pessoas cristãs que se organizam em um determinado local para desenvolver a obra de Deus, independentemente da denominação". Não estamos falando aqui de uma igreja instituição, não sabemos se uma instituição com o perfil e atuação que apontamos existe ou existirá. Com certeza, existem igrejas sérias e comprometidas. Porém, demonstramos uma Igreja, sem placa denominacional e sem víeis (católica ou protestante), formada por pessoas que possuem seus problemas, suas limitações, suas angustias e com certeza suas próprias necessidades. Contudo, assimilaram que a proposta do evangelho é prática e práxis. Compreenderam que é no outro que encontramos e nos aproximamos de Deus. Entenderam que é na unidade que a Igreja realiza sua ação social e se manifesta à sociedade, nas palavras de Jesus:

"Para que todos sejam um, como tu, ó Pai, o és em mim, e eu em ti; que também eles sejam um em nós, para que o mundo creia que tu me enviaste.” (Jo 17.21) 
É de Alfred Firmin Loisy (apud GONÇALVES, 2009, p. 33) a frase: "Jesus pregou o

Reino e o que veio foi a Igreja". Uma igreja que encontrou seu caminho na unidade do

Corpo, na graça e na certeza da paternidade de Deus. Neste sentido, Rui de Souza

Josgrilberg nos diz:

Este então é o caminho: caminhe por ele, quem quer que vocês sejam, mas que crêem no nome de Cristo. Vocês sabem: 'ninguém pode por outro fundamento além do que já foi posto: Jesus Cristo'. Vocês sabem também que foram salvos pela graça mediante a fé; salvos do pecado por 'Cristo nascido em seus corações'; e do temor, porque 'o Espírito testemunha com o nosso espírito que somos filhos de Deus'. (JOSGRILBERG, 2003, p. 111)

Está é a convicção da Igreja, de ser filho/a de Deus. É o que faz a Igreja prosseguir, contra todas as diversidades e problemáticas apresentadas, tendo a consciência de que fomos salvos pela graça e, que somente por ela, Deus continua a salvar. Uma boa representatividade musical para esta atuação da Igreja em sua missão de anunciar e de apresentar o amor de Deus seria a música Deus chama todos os povos da Comunidade da Vila da Penha;

Deus chama todos os povos e todas as nações,

Todos os homens, todas as mulheres

E todos os jovens

Ao arrependimento, ao plano da salvação

Venham todos porque não há acepção.

O Senhor, o Criador quer que todos tenham vida.

O Senhor, o Criador ainda ama o que criou.

Porque o amor de Deus é além do céu

Que enviou o Senhor Jesus

O seu único Filho, o seu amado Filho.

Venham.. todos que querem vida,

Tem sede de água viva

E que andar na luz;

O que procura a paz

Que tem sede de justiça

E quer vencer o mal

O escapar da morte

$\mathrm{O}$ ter vida eterna

Não está em religiões

Mas sim no homem

Se voltar para Deus

E crer em Cristo...Jesus. 


\section{Considerações finais}

O desenvolvimento do presente estudo possibilitou compreender como a Igreja, desde o século I, está envolvida com a sociedade e seus problemas. Permitiu uma reflexão sobre a questão do mandamento do amor ao próximo apresentado no Antigo Testamento e sua releitura feita por Jesus no Novo Testamento, onde a partir desta reflexão é instituída uma nova ordem social que atravessa o tempo e passa a nortear as ações da Igreja. Além disso possibilitou compreender que a Igreja encontra-se inserida na cultura da sociedade e do tempo devendo a Igreja, no seu tempo e na sociedade onde está inserida, entender e compreender esta cultura para encontrar a forma de comunicar e se comunicar coadunando ortodoxia e práxis.

De uma forma geral demonstrou-se aos leitores que a Igreja é integrada a sociedade e com ela vive e vivencia suas causas, problemas, dilemas e as interferências que a cultura e o tempo em que estão trazem como desafio. A igreja de Jerusalém entendeu a proposta do amor ao próximo de forma tal que se doava para possibilitar o auxílio ao próximo. Na Igreja do século XXI, encontramos uma igreja que não para, que continua demonstrando sua importância social através de suas ações, mas que precisa aprender a se comunicar no virtual para encontrar a pessoa real. A igreja contemporânea, apesar da influência da sociedade do espetáculo, não encontra-se na mídia, ela está onde precisa estar, ou seja, ela ainda aplica-se em servir ao mundo através da diaconia, de sua espiritualidade e em continuidade ao mandamento de amar ao próximo.

Através dos resultados apresentados na pesquisa foi possível verificar que em cada etapa e ou seção identificou-se que apesar do tempo e da cultura em que a Igreja encontrase e dos desafios que surgem ela permanece firme no seu propósito de servir. Assim, verifica-se que os objetivos apresentados foram alcançados.

Com a pesquisa foi possível aprender que o indicador orientador ou a força motriz da Igreja continua sendo o mandamento imutável do amor ao próximo. Este mandamento quando compreendido e assimilado pela Igreja traz grandes aplicabilidades na vida comunitária e para a comunidade onde a Igreja está inserida, pois este entendimento resultará em ações práticas de auxílio e resgate. Trará mudanças na prática religiosa, pois as leituras e reflexões da Bíblia serão em relação a missão de Deus através da vida da Igreja. 
Data a importância e a abrangência do tema, torna-se necessário estudos direcionados sobre a influência que a cultura, a mídia e o modo de vida que a sociedade vai assimilando trazem como desafios para a Igreja, bem como, na formação de líderes que possam desenvolver capacidades e habilidades para conduzirem suas Igrejas locais a efetividade de ações sociais relevantes que propiciem o auxílio e o resgate.

Sendo assim, a pesquisa demonstrou que a Igreja é integrada à sociedade e que não é somente um grupo religioso que se reuni para adorar a um Deus invisível. Antes, que demonstra na prática de sua vivência que ela é um corpo vivo e social que através de suas ações demonstram um Deus real que se preocupa com a integralidade do ser humano e tem na Igreja um canal, para aqueles e aquelas que estejam perdidos e postos a margem da sociedade, sejam alcançados, resgatados e cuidados, tendo sua dignidade humana restabelecida. 


\section{Referências bibliográficas}

ASLAN, Reza. Zelota: a vida e a época de Jesus de Nazaré. Tradução de Marlene Suano. Rio de Janeiro: Zahar, 2013. 303 p. ISBN 9788537811528.

AZEVEDO, Marcos. Ética \& Espiritualidade: em busca de uma cidadania integral. São Paulo: Fonte Editorial, 2015. 116 p. ISBN 9788568252345.

BAUMAN, Zygmunt. O mal-estar da pós-modernidade. Tradução de Mauro Gama, Cláudia Martinelli Gama. Rio de Janeiro, RJ: Jorge Zahar, 1998. 272 p. ISBN 85-7110-464-6.

BÍBLIA E HARPA CRISTÃ: Bíblia Sagrada contendo o Antigo e o Novo Testamento. Tradução de João Ferreira de Almeida. Baurueri, SP: Sociedade Bíblica do Brasil: Rio de Janeiro: Publicadora das Assembleias de Deus, 2003. 1536 p.

CASTRO, Clovis Pinto de. Por uma fé cidadã: a dimensão pública da Igreja: fundamentos para uma Pastoral da Cidadania. São Bernardo do Campo: UMESP: Loyola, 2000. 134 p. (Ciências da religião, 4). ISBN 8515021978.

ESTADO RS.GOV. Segurança publica quer ampliar atuação de igrejas no sistema prisional. Disponível em: <https://estado.rs.gov.br/seguranca-publica-quer-ampliar-atuacao-de-igrejas-nosistema-prisional> Acessado em 22 mai. 2018

FOLHA DE SÃO PAULO. Igrejas atuam onde Estado não pisa para atender usuários na cracolândia. Disponível em: http://www1.folha.uol.com.br/cotidiano/2017/06/1890248-igrejasatuam-onde-estado-nao-pisa-para-atender-usuarios-na-cracolandia.shtml Acessado em 12 mai. 2018

FOSTER, Richard J. A liberdade da simplicidade: encontrando harmonia num mundo complexo. São Paulo: Vida, 2008.

G1 SÃO PAULO. Pastora trabalha há mais de 10 anos na Cracolândia e já adotou 2 filhos de usuários. Disponível em: https://g1.globo.com/sao-paulo/noticia/pastora-trabalha-ha-mais-de10-anos-na-cracolandia-e-ja-adotou-2-filhos-de-usuarios.ghtml Acessado em 12 mai. 2018

GIANASTACIO, Vanderlei. Responsabilidade social, serviço e cidadania: à luz da Igreja primitiva. 2. ed. São Paulo: Vida Nova, 2012. 143 p. ISBN 9788527503556.

GONÇALVES, Alonso. Reino de Deus e práxis pastoral. Uma abordagem a partir da teologia de Jon Sobrinho. Ciberteologia - Revista de Teologia \& Cultura - Ano III, n. 23 - Maio/Junho 2009 - ISSN: 1809-2888. Disponível em: http://ciberteologia.paulinas.org.br/ciberteologia/index.php/artigos/reino-de-deus-e-praxispastoral-uma-abordagem-a-partir-da-teologia-de-jon-sobrino/. Acessado em: 2222 mai. 2018.

GRENZ, Stanley J. Pós-modernismo: um guia para entender a filosofia do nosso tempo. Tradução de Antivan Guimarães Mendes. São Paulo: Vida Nova, 2008. 256 p. ISBN 9788527503877.

JOSGRILBERG, Rui de Souza. A motivação originária da teologia wesleyana: o caminho da salvação. Caminhando, São Bernardo do Campo, v. 8, n. 12, p.103-124., 2003.

LYOTARD, Jean-Francois. O pós-moderno. Tradução de Ricardo Correa Barbosa. 3.ed. Rio de Janeiro: José Olympio, 1998. 125 p. ISBN 85-03-00080-6. 
O GLOBO. Evangélicos marcam território dentro dos presídios do Rio. Disponível em: < https://oglobo.globo.com/rio/evangelicos-marcam-territorio-dentro-dos-presidios-do-rio16251517 > Acessado em 22 mai. 2018

O SÃO PAULO. A experiência de Nova York. Disponível em: http://www.osaopaulo.org.br/taxonomy/term/202 Acessado em 12 mai. 2018

RAMOS, Luiz Carlos. A sociedade do espetáculo e o discurso religioso. Caminhando, São Bernardo do Campo, v. 13, n. 22, p. 141-154., jul./dez. 2008.

Igreja, culto e missão: Considerações eclesiológicas e missiológicas sobre a liturgia cristã. Luiz Carlos Ramos Textos \& Texturas, 2015. Disponível em: http://www.luizcarlosramos.net/igreja-culto-e-missao/. Acessado em: 13 abr. 2018

REDE SOLIDÁRIA IBAB. AEBVB - Associação Educacional e Beneficente Vale da Benção. Disponível em: < http://redeibabsolidaria.com.br/portfolios/associacao-educacional-ebeneficente-vale-da-bencao-aebvb/ > Acessado em 22 mai. 2018

RENDERS, Helmut. A soteriologia social de John Wesley. 2006. 404 p. Tese (Doutorado em Ciências da Religião) - Faculdade de Filosofia e Ciências da Religião, Universidade Metodista de São Paulo, São Bernardo do Campo. Disponível em: <http://tede.metodista.br/jspui/handle/tede/392>. Acesso em: 22 mai. 2018.

SCHAEFFER, Francis A. A morte da razão. São Paulo: Aliança Bíblica Universitária do BrasilABU Editora, 2014. Projeto Democratização da Leitura. Disponível em: https://pt.scribd.com/document/353722090/A-MORTE-DA-RAZAO-FRANCIS-SCHAEFFERpdf. Acessado em: 10 Abr 2018

SILVA, Geoval Jacinto da. Abrindo espaços para a práxis da missão de Deus. São Bernardo do Campo: Ed. do Autor, 2009. 128 p. ISBN 9788591004409.

SILVA, Maria Freire da; XAVIER, Donizete José (Org.). Pensar a fé teologicamente. São Paulo: Paulinas, 2007. 296 p. ISBN 9788535620771.

THEISSEN, Gerd. A religião dos primeiros cristãos: uma teoria do cristianismo primitivo. Tradução de Paulo F. Valério. São Paulo: Paulinas, 2009. 450 p. (Cultura bíblica). ISBN 9788535624069.

Visão Mundial. Relatório Anual $17 . \quad$ Disponível em: https://issuu.com/visaomundialbr/docs/ra2018_vmb_v9_semsangria?e=24782718/60129931. Acessado em: 13 abr. 2018

ZABATIERO, Julio Paulo Tavares. Fundamentos da teologia prática. São Paulo: Mundo Cristão, 2005. 135 p. (Teologia brasileira). ISBN 85-7325-417-3. 